AGRITECH, Vol. 37, No. 1, Februari 2017, Hal. 69-76 DOI: http://dx.doi.org/10.22146/agritech.17012 ISSN 0216-0455 (Print), ISSN 2527-3825 (Online) Tersedia online di https://jurnal.ugm.ac.id/agritech/

\title{
Pengaruh Jenis Asam dan Waktu Reaksi Pemanasan terhadap Karakteristik Produk Etanolisis PKO (Palm Kernel Oil)
}

\author{
Effect of Organic Acids and Reaction Times on Characteristics of Palm Kernel Oil (PKO) Derivative Product \\ by Ethanolisis Reaction
}

\section{Murhadi, Sri Hidayati, Ridwan Kurniawan}

\begin{abstract}
Jurusan Teknologi Hasil Pertanian, Fakultas Pertanian Universitas Lampung,Jl. Prof. Soemantri Brojonegoro No. 1
Kampus Unila Gedung Meneng, Bandar Lampung, Provinsi Lampung 35145, Indonesia

Email: murhadiburcik@gmail.com; murhadi.1964@fp.unila.ac.id
\end{abstract}

Submisi: 21 Desember 2015; Penerimaan: 26 Februari 2016

\begin{abstract}
ABSTRAK
Produksi produk etanolisis dari minyak inti sawit (Palm Kernel Oil, PKO) dengan perlakuan penambahan asam organik dan lama pemanasan yang berbeda telah dilakukan. Penelitian ini dilakukan untuk melihat pengaruh penambahan jenis asam dan lama pemanasan terhadap karakteristik produk etanolisis dari PKO. Asam organik yang digunakan adalah asam suksinat $40 \%(\mathrm{~b} / \mathrm{b})$ dan asam laktat $40 \%(\mathrm{~b} / \mathrm{b})$ serta lama pemanasan terdiri dari $15,30,45$, dan 60 menit. Nilai $\mathrm{pH}$ produk reaksi berkisar antara 4,88 $( \pm 0,01)$ sampai $5,27( \pm 0,02)$. Aktivitas anti mikroba produk reaksi terbaik adalah dengan penambahan asam suksinat $40 \%(\mathrm{~b} / \mathrm{b})$ dan pemanasan 30 menit dengan diameter $(\mathrm{d} ; \mathrm{mm})$ zona hambat terhadap Staphylococus aureus ATCC 25923, Escherichia coli ATCC 25922, kultur campuran mikroba alami dan Saccharomyces cerevisiae, masing-masing 20,88 $( \pm 0,50) \mathrm{mm}, 25,64( \pm 0,81) \mathrm{mm}, 6,46( \pm 0,24) \mathrm{mm}$, dan 8,84 $( \pm 0,08)$ $\mathrm{mm}$. Nilai rata-rata daya peningkatan stabilitas emulsi pada santan kelapa (water in oil, w/o) berkisar antara 5,20 ( \pm $0,65) \%$ hingga $20,00( \pm 2,55) \%$.
\end{abstract}

Kata kunci: Aktivitas antimikroba; stabilitas emulsi; etanolisis; Palm Kernel Oil (PKO)

\begin{abstract}
Production of ethanolisis product of Palm Kernel Oil (PKO) treatment with the addition of organic acids and different heating times have conducted. Effects of organic acids used and time of heating on characteristics of PKO ethanolisis product were studied. The organic acids used are succinic acid $40 \%(\mathrm{w} / \mathrm{v})$ and lactic acid $40 \%(\mathrm{w} / \mathrm{v})$. Heating time consists of 15, 30, 45 and 60 minutes. The $\mathrm{pH}$ value of the reaction products ranged from 4,88 $( \pm 0,01)$ to $5,27( \pm 0,02)$. The best antimicrobial activity of product reaction is by addition of succinic acid $40 \%(\mathrm{w} / \mathrm{v})$ and heating for 30 minutes with zone of inhibitions (d, mm) against Staphylococus aureus ATCC 25923, Escherichia coli ATCC 25922, mixed cultures of natural microbial and Saccharomyces cerevisiae are 20,88 $( \pm 0,50) \mathrm{mm}, 25,64( \pm 0,81) \mathrm{mm}, 6,46( \pm 0,24)$ $\mathrm{mm}$, and $8,84( \pm 0,08) \mathrm{mm}$, respectively. The average value of the power increase emulsion stability in coconut milk (water in oil, w/o) ranged from $5,20( \pm 0,65) \%$ to $20,00( \pm 2,55) \%$.
\end{abstract}

Keywords: Antimicrobial activity; emulsion stability; ethanolisis; Palm Kernel Oil (PKO) 


\section{PENDAHULUAN}

Kebutuhan Crude Palm Oil (CPO) diprediksi terus meningkat. Dengan berkembangnya agroindustri pengolahan buah sawit untuk menghasilkan CPO, maka diprediksi pula produksi minyak inti sawit (Palm Kernel Oil, PKO) juga meningkat. PKO merupakan hasil samping dari agroindustri pengolahan CPO. Komposisi asam lemak PKO sangat berbeda dengan CPO, karena lebih banyak mengandung asam laurat (12:0), sementara asam lemak jenuh dan tidak jenuh berantai panjang $(16: 0,18: 0,18: 1)$ jumlahnya jauh lebih sedikit dibandingkan dengan CPO. Komposisi asam lemak dominan pada CPO terdiri dari palmitat $(16: 0 ; 44,16 \%)$, oleat (18:1; 36,6 \%), dan linoleat $(18: 2 ; 9,71 \%)$ (Murhadi dan Suharyono, 2012). Jumlah asam lemak total di dalam PKO yang diekstraksi menggunakan heksana adalah 99,42 g (99,42 \%) per 100 g PKO (Murhadi, 2010a). Jenis asam lemak yang terkandung di dalam PKO terdiri dari 9 jenis asam lemak yaitu terbagi ke dalam 7 jenis asam lemak jenuh didominasi oleh asam laurat $(12: 0 ; 49,39 \%)$ dan asam miristat (14:0; $15,35 \%)$ serta 2 asam lemak tidak jenuh yang didominasi oleh asam oleat $(18: 1 ; 15,35 \%)$ dan asam linoleat $(18: 2 ; 3,10$ \%) (Murhadi, 2010a). Komposisi asam lemak utama PKO hampir mirip dengan komposisi asam lemak utama dalam minyak kelapa (coconut oil) dengan kandungan utama asam laurat dan miristat.

Beberapa hasil penelitian menunjukkan bahwa produk monogliserida dalam bentuk monolaurin (12:0) dan monomiristin (14:0) terbukti mempunyai aktivitas anti bakteri (Gram + dan Gram -), kamir, dan kapang dengan spektrum luas (Wang dkk., 1993; Bautista dkk., 1993; Oh dan Marshall, 1994; Cotton dan Marshall, 1997; Mappiratu, 1999; Mappiratu dkk., 2003; Rangga dkk., 2005), bahkan juga terbukti sebagai anti sel-sel tumor dan HIV-1 (Kovacs dkk., 1999). Dari beberapa hasil penelitian kami (Murhadi dan Suharyono, 2008; Lestari dan Murhadi, 2008; Murhadi, 2009; Murhadi, 2010a; Murhadi dkk., 2010; Kurniawan dkk., 2014) terbukti PKO berpotensi untuk diproses lebih lanjut menjadi produk yang mengandung monogliserida dan atau digliserida yang memiliki fungsi ganda baik sebagai emulsifier sekaligus sebagai pengawet pangan. PKO sering digunakan oleh industri oleokimia sebagai bahan baku/dasar untuk menghasilkan produk surfaktan dan emulsifier. Kandungan asam laurat yang tinggi pada PKO menjadi salah satu kelebihan tersendiri karena asam lemak ini berkhasiat bagi kesehatan tubuh, yang telah dibuktikan dan dikembangkan pada produk-produk minyak yang mengandung asam laurat (Affandi, 2007). Aplikasi mono-diasilgliserol dari Fully Hydrogenated Palm Kernel Oil (FHPKO) sebagai emulsifier untuk margarin juga telah dilakukan. Berdasarkan hasil aplikasi dan evaluasi sensori terhadap tekstur aroma dan flavor produk pound cake dan roti manis dari margarin emulsifier MDAG dari FHPKO menunjukkan bahwa produk tersebut mirip dengan profil emulsifier komersial yang menunjukkan bahwa MDAG dari FHPKO dapat dijadikan sebagai emulsifier alternatif untuk margarin (Triana dkk., 2014).

Suharyono dkk. (2013), melaporkan adanya aktivitas antibakteri produk etanolisis $\mathrm{PKO}$ dengan penambahan asam laktat atau suksinat pada suhu $60{ }^{\circ} \mathrm{C}$ yang diaduk selama 15 menit dengan nilai diameter zona hambat terhadap Staphylococcus aureus ATCC 25923, Escherichia coli ATCC 25922, Sacharomyces cerevisiae dan kultur campuran mikroba alami, masing-masing adalah 11,04, 12,62, 4,74, dan 3,39 mm. Kurniawan dkk. (2014), melaporkan bahwa jenis asam organik (laktat dan suksinat), suhu pemanasan (40 s.d. $70^{\circ} \mathrm{C}$ ), serta interaksi antara keduanya berbeda nyata terhadap derajat keasaman $(\mathrm{pH})$, aktivitas antimikroba (anti $S$. aureus, anti E. coli, anti-Kultur mikroba alami, dan anti S. cerevisiae) dan daya stabilitas emulsi pada santan kelapa. Selanjutnya penelitian pengararuh jenis asam organik dan lama pemanasan produk etanolisis $\mathrm{PKO}$ pada $60^{\circ} \mathrm{C}$ terhadap karakteristik produk yang dihasilkan belum dilakukan. Penelitian ini bertujuan menghasilkan produk etanolisis PKO dengan penambahan asam organik yang memiliki daya antimikroba tinggi dan daya stabilitas emulsi yang lebih baik.

\section{METODE PENELITIAN}

\section{Alat dan Bahan}

Alat-alat yang digunakan adalah hotplate stirrer, inkubator, labu pemisah (separating funnel) glass $500 \mathrm{~mL}$, oven, sentrifuse $4.000 \mathrm{rpm}$, lemari pendingin, penangas air, autoklaf, mikropipet, vortex, $4.000 \mathrm{rpm}$, timbangan analitik, termometer, jangka sorong, dan alat-alat gelas penunjang yang digunakan saat pengolahan dan analisis.

Bahan utama adalah PKO, diperoleh dari PTPN 7 Unit Usaha Bekeri Lampung Tengah dan santan kelapa segar untuk uji daya stabilitas emulsi (o/w). Bahan kimia terdiri dari etanol teknis $96 \%, \mathrm{NaOH}, \mathrm{HCl} 35 \%$, asam suksinat, asam laktat, dan aquades. Kultur mikroba yaitu Staphylococus aureus ATCC 25923, Escherichia coli ATCC 25922, khamir Saccharomyces cereviciae dan kultur campuran mikroba alami. Media terdiri dari NA (Nutrient Agar) dan NB (Nutrient Broth).

\section{Pelaksanaan Penelitian}

Penelitian ini disusun secara faktorial dalam Rancangan Acak Kelompok Lengkap (RAKL) dengan tiga kali ulangan, faktor pertama adalah jenis asam organik (asam suksinat $40 \%, \mathrm{~b} / \mathrm{b}$ dan asam laktat $40 \%, \mathrm{~b} / \mathrm{b}$ ) dan faktor kedua adalah suhu pemanasan $\left(40,50,60\right.$ dan $\left.70^{\circ} \mathrm{C}\right)$. Data kemudian diolah lebih lanjut dengan perbandingan Ortogonal polynomial pada 
taraf nyata $1 \%$ dan $5 \%$. Sedangkan data untuk \%tase daya stabilitas emulsi disajikan dalam bentuk grafik yang dibahas secara deskriptif. Tahapan penelitian meliputi: (1) produksi produk etanolisis dari PKO dan (2) penambahan asam organik ke dalam produk etanolisis $\mathrm{PKO}$ pada suhu $60^{\circ} \mathrm{C}$ dengan lama pengadukan dan pemanasan berbeda. Pengamatan terdiri dari pengukuran nilai $\mathrm{pH}$, pengujian aktivitas antimikroba dan daya stabilitas emulsi.

\section{Produksi Produk Etanolisis dari PKO}

Reaksi etanolisis PKO dilakukan mengikuti metode Murhadi dan Zuidar (2009) dan Murhadi (2010a) dengan modifikasi. Sejumlah $128 \mathrm{~mL}$ etanol $96 \%$ yang telah mengandung $\mathrm{NaOH}$ 1\% (b/b PKO) ditambahkan 80 g PKO di dalam Erlenmayer $500 \mathrm{~mL}$ dengan total volume reaksi etanolisis kurang lebih $210 \mathrm{~mL}$ (nisbah = 1,6; v/b), diletakkan di atas hotplate stirrer dengan kecepatan putar $1000 \mathrm{rpm}$ selama 8 menit pada suhu reaksi gliserolisis $40^{\circ} \mathrm{C}$. Reaksi dihentikan dengan meneteskan sebanyak 21 tetes larutan HCL 35\%. Campuran produk reaksi dimasukkan ke dalam labu pemisah dan dibiarkan selama 30 menit, sehingga telah terlihat jelas pemisahan antar lapisan. Lapisan atas (produk etanolisis kasar, berwarna putih kuning pucat) dipisahkan dari lapisan bawah (sisa PKO, berwarna kuning cerah). Produk etanolisis $\mathrm{PKO}$ dimasukkan ke dalam oven $60^{\circ} \mathrm{C}$ selama 24 jam sehingga dihasilkan produk etanolisis pekat.

\section{Penambahan Asam Organik ke Dalam Produk Etanolisis PKO}

Penambahan asam organik ke dalam produk etanolisis PKO menggunakan asam laktat atau suksinat untuk dapat membentuk produk emulsifier (Fennema, 1985) sebagai emulsifier plus (berfungsi juga sebagai pengawet). Sejumlah $25 \mathrm{~mL}$ produk etanolisis PKO (setara 2,5 g berat kering tanpa pelarut etanol 96\%) ditambah 2,5 mL gliserol dan 1,0 $\mathrm{g}$ asam organik (laktat atau suksinat ) di dalam Erlenmeyer $50 \mathrm{~mL}$ (Kurniawan dkk., 2014), diaduk (stirrer, $1000 \mathrm{rpm}$, $60^{\circ} \mathrm{C}$ ) selama 15, 30, 45 atau 60 menit, lalu diamati. Produk etanolisis PKO yang telah ditambah asam organik (laktat atau suksinat) dan dipanaskan $\left(60^{\circ} \mathrm{C}\right)$ selama $15,30,45$ atau 60 menit, selanjutnya disebut emulsifier plus PKO.

\section{Pengamatan}

Pengamatan terdiri dari pengukuran nilai $\mathrm{pH}(\mathrm{pH}$ meter), uji aktivitas antimikroba menggunakan metode sumur (Gariga dkk., 1983; Murhadi dkk., 2007 Murhadi, 2010a), dan pengujian daya stabilitas emulsi (Malik dkk., 1987; Murhadi, 2009; Murhadi, 2010b). Menurut Murhadi (2010a), metode sumur dilakukan dengan cara kultur bakteri murni disegarkan kembali dalam tabung yang berisi medium cair steril (NB atau media cair yang diperkaya), diinkubasi 24 jam pada $37^{\circ} \mathrm{C}$ (atau sesuai jenis bakteri), dihomogenkan dengan vorteks, lalu diinokulasikan $20 \mu \mathrm{L}$ ke dalam Erlenmeyer yang berisi $20 \mathrm{~mL}$ medium agar cair (NA atau media agar yang sesuai, $44-45^{\circ} \mathrm{C}$ ) steril, dikocok merata, kemudian dituang ke dalam cawan petri steril dan dibiarkan sampai membeku. Selanjutnya dibuat 3-5 lubang (sumur) secara aseptis dengan diameter sumur $6,0 \mathrm{~mm}$ (seragam). Ke dalam tiap dari 4 sumur (bagian pinggir petri), diinokulasi dengan $60 \mu \mathrm{L}$ ekstrak organik tanaman yang telah diencerkan sesuai hasil uji pendahuluan. Sebagai kontrol, diinokulasi sebanyak 60 $\mu \mathrm{L}$ pelarut pengencer (selain air murni) ke dalam sumur uji di bagian tengah petri. Zona penghambatan yang diukur adalah radius ( $\mathrm{r}, \mathrm{mm}$ ) penghambatan berupa areal bening di sekeliling sumur uji, setelah diinkubasi selama 24 jam pada $37^{\circ} \mathrm{C}$ (sesuai jenis bakteri uji). Pengukuran jari-jari $\left(r_{p}\right.$, $\mathrm{mm}$ ) zona hambat di sekeliling sumur uji dilakukan dengan cara mengukur jarak dari tepi sumur uji ke batas lingkaran terluar zona hambat menggunakan jangka sorong (ketelitian $0,01 \mathrm{~mm}$ ) pada beberapa sisi sumur uji, lalu dirata-ratakan. Perhitungannya sebagai berikut.

1. Dihitung luas kotor $\left(\mathrm{L}_{1}, \mathrm{~mm}^{2}\right)$ lingkaran areal bening akibat daya hambat bakteri uji di sekeliling sumur uji dengan persamaan luas: $L_{1}=\pi \cdot r_{1}^{2}$, dimana $r_{1}=r_{p}+r_{s}, r_{p}$ $=$ jarak dari lingkaran luar sumur uji ke lingkaran terluar areal bening di sekeliling sumur uji $(\mathrm{mm}), \mathrm{r}_{\mathrm{s}}=$ jari-jari sumur uji (mm), dan $\pi=3,14$.

2. Dihitung luas kontrol $\left(\mathrm{L}_{2}, \mathrm{~mm}^{2}\right)$ areal bening akibat daya hambat pelarut organik yang digunakan sebagai pengencer dengan persamaan luas, yaitu: $\quad \mathrm{L}_{2}=\pi \cdot \mathrm{r}_{2}^{2}$, dimana $r_{2}=r_{k}+r_{s}, r_{k}=$ jarak dari lingkaran luar sumur ke lingkaran terluar areal bening di sekeliling sumur uji $(\mathrm{mm})$ akibat daya hambat pelarut/pengencer organik, $r$ $=$ jari-jari sumur uji (mm), dan $\pi=3,14$.

3. Dihitung luas bersih $\left(\mathrm{L}_{3}, \mathrm{~mm}^{2}\right)$ dengan persamaan: $\mathrm{L}_{3}=$ $\mathrm{L}_{1}-\mathrm{L}_{2}$.

4. Dihitung jari-jari zona hambat riil $\left(r_{r}, \mathrm{~mm}\right)$ dengan persamaan: $\mathrm{r}_{\mathrm{r}}=\sqrt{ }\left(\mathrm{L}_{3} / 3,14\right)$.

5. Akhirnya dihitung nilai diameter zona hambat riil $\left(\mathrm{d}_{\mathrm{r}}\right.$, $\mathrm{mm}$ ) dengan persamaan: $d_{r}=2 \cdot r_{r}$.

\section{HASIL DAN PEMBAHASAN}

\section{Nilai pH (Derajat Keasaman)}

Nilai $\mathrm{pH}$ produk emulsifier plus PKO untuk semua perlakuan berkisar antara 4,88 $( \pm 0,01)$ sampai 5,27 $( \pm 0,02)$. Hasil analisis ragam menunjukan bahwa pengaruh jenis asam dan lama pemanasan produk emulsifier plus PKO berbeda nyata pada taraf nyata $1 \%$. Interaksi antara jenis asam dan lama pemanasan produk emulsifier plus PKO juga berbeda 


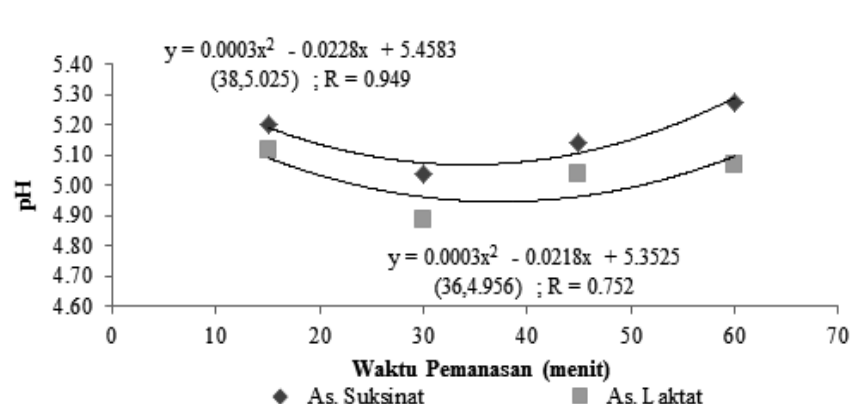

Gambar 1. Nilai $\mathrm{pH}$ produk emulsifier plus PKO pada lama pemanasan (60 ${ }^{\circ} \mathrm{C}$ ) berbeda

nyata terhadap nilai $\mathrm{pH}$ produk. Hasil uji lanjut polinomial ortogonal menunjukan bahwa hubungan jenis asam organik dan masing-masing lama pemanasan bersifat kuadratik menurunkan dan menaikkan nilai $\mathrm{pH}$ produk emulsifier plus PKO (Gambar 1).

Produk emulsifier plus PKO dengan penambahan asam suksinat pada pemanasan 15 menit menghasilkan nilai $\mathrm{pH}$ sebesar 5,20, terjadi penurunan $\mathrm{pH}$ setelah pemanasan 30 menit menjadi 5,03, lalu mengalami kenaikan kembali terhadap nilai $\mathrm{pH}$ setelah pemanasan 45 dan 60 menit dengan nilai $\mathrm{pH} 5,14$ dan 5,77. Pola yang hampir sama terjadi pada perlakuan dengan penambahan asam laktat dengan nilai ratarata $\mathrm{pH}$ untuk semua perlakuan lama pemanasan lebih rendah dibandingkan dengan perlakuan penambahan asam suksinat (Gambar 1). Hal ini menunjukkan bahwa lama pemanasan pada penambahan asam organik dalam produk etanolisis PKO bersifat bolak balik sehingga mempengaruhi nilai $\mathrm{pH}$ yang dihasilkan pada produk emulsifier plus PKO. Nilai $\mathrm{pH}$ berbanding lurus dengan $\mathrm{pKa}$ asam yang merupakan salah satu faktor utama yang mempengaruhi kelarutan asam dalam suatu larutan. Nilai pKa asam laktat lebih rendah dibandingkan asam suksinat. Asam laktat memiliki nilai pKa sebesar 3,08 sedangkan asam suksinat memiliki nilai pKa sebesar 4,2. Hasil penelitian ini menunjukkan bahwa nilai $\mathrm{pH}$ produk emulsifier plus $\mathrm{PKO}$ dengan penambahan asam laktat relatif lebih rendah bila dibandingkan dengan $\mathrm{pH}$ produk dengan penambahan asam suksinat. Hasil penelitian Kurniawan dkk (2014) menunjukkan bahwa terjadi pola penurunan nilai $\mathrm{pH}$ baik untuk penambahan asam laktat maupun penambahan asam suksinat pada perlakuan berbagai suhu pemanasan (40, 50,60 dan $70^{\circ} \mathrm{C}$ ) dengan rata-rata nilai $\mathrm{pH}$ produk emulsifier plus $\mathrm{PKO}$ dengan penambahan asam laktat relatif lebih rendah bila dibandingkan dengan $\mathrm{pH}$ produk dengan penambahan asam suksinat.

\section{Aktivitas Anti $S$. Aureus}

Secara umum nilai diameter zona hambat $(\mathrm{d} ; \mathrm{mm})$ produk emulsifier plus PKO yang dipanaskan $\left(60^{\circ} \mathrm{C}\right)$ selama

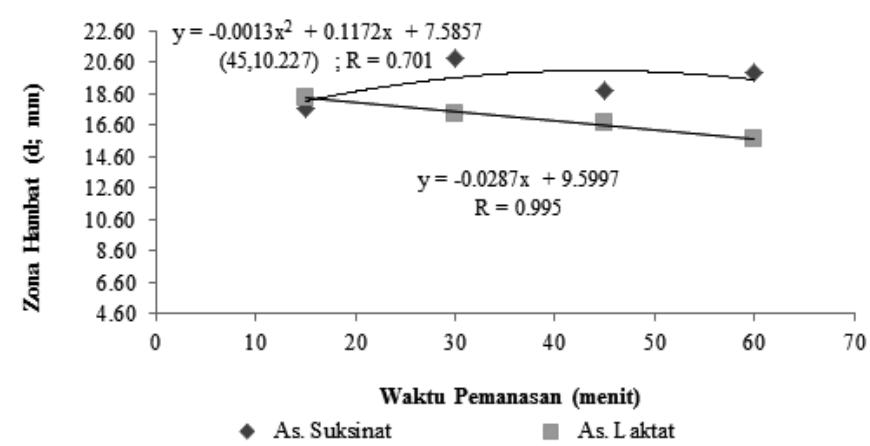

Gambar 2. Aktivitas anti $S$. aureus produk emulsifier plus PKO pada lama pemanasan $\left(60^{\circ} \mathrm{C}\right)$ berbeda

15 s.d. 60 menit terhadap $S$. aureus adalah $15,73( \pm 0,24)$ sampai 20,88 $( \pm 0,50) \mathrm{mm}$. Hasil analisis ragam menunjukan bahwa perlakuan jenis asam organik dan lama pemanasan berbeda nyata pada aktivitas anti $S$. aureus dengan taraf nyata $1 \%$. Interaksi antara jenis asam organik dan lama pemanasan juga menunjukkan beda nyata pada taraf nyata $1 \%$. Hasil uji lanjut polinomial ortogonal (Gambar 2) menunjukan bahwa hubungan antara jenis asam organik dan lama pemanasan pada aktivitas anti $S$. aureus bersifat kuadratik.

Aktivitas anti $S$. aureus tertinggi terdapat pada produk emulsifier plus PKO dengan penambahan asam suksinat $40 \%$ setelah pemanasan 30 menit dengan nilai diameter zona hambat sebesar 20,88 $( \pm 0,50) \mathrm{mm}$, sedangkan pada perlakuan penambahan asam laktat $40 \%$ setelah pemanasan 15 menit menghasilkan nilai tertinggi yaitu 18,39 ( \pm $0,55) \mathrm{mm}$, selanjutnya dengan pola terus menurun setelah pemanasan 30, 45, dan 60 menit. Aktivitas anti $S$. aureus mengalami peningkatan paling signifikan pada penambahan asam suksinat setelah pemanasan 30 menit. Hasil penelitian Suharyono dkk. (2013) menghasilkan diameter zona hambat sebesar 11,04 mm pada bakteri yang sama. Aktivitas anti $S$. aureus yang dihasilkan pada penelitian ini tergolong ke dalam kategori aktivitas antibakteri tinggi, karena memiliki nilai diameter zona hambat lebih dari $12 \mathrm{~mm}$. Senyawa antibakteri dikatakan memiliki aktivitas antibakteri tinggi apabila diameter zona hambatnya lebih dari $12 \mathrm{~mm}$, tergolong sedang jika antara 9-12 mm, tergolong kurang aktif jika antara 6-9 $\mathrm{mm}$ dan tergolong sangat lemah jika kurang dari $6 \mathrm{~mm}$ (ElMasry dkk., 2000).

\section{Aktivitas Anti E. Coli}

Aktivitas anti E. coli produk emulsifier plus PKO secara umum memiliki rentang nilai diameter zona hambat antara $20,55( \pm 0,37)$ sampai 25,64 $( \pm 0,81) \mathrm{mm}$. Hasil analisis ragam menunjukan bahwa penambahan jenis asam organik dan lama pemanasan berbeada nyata pada aktivitas anti $E$. coli dengan taraf nyata $1 \%$. Hasil analisis ragam juga berpengaruh pada 


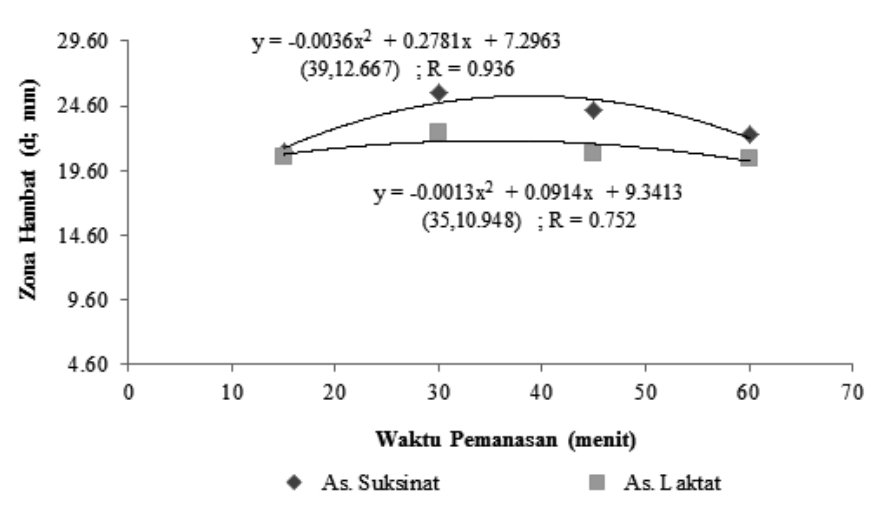

Gambar 3. Aktivitas anti E. coli produk emulsifier plus PKO pada lama pemanasan $\left(60^{\circ} \mathrm{C}\right)$ berbeda

interaksi antara jenis asam dengan lama pemanasan yang digunakan pada masing-masing perlakuan menunjukkan berbeda nyata pada taraf $1 \%$. Hasil uji lanjut polinomial ortogonal (Gambar 3) menunjukan bahwa hubungan antara penambahan jenis asam organik dengan lama pemanasan terhadap aktivitas anti $E$. coli bersifat kuadratik.

Nilai diameter zona hambat tertinggi dari perlakuan penambahan asam suksinat lebih tinggi $(d=25,64 \pm 0,81 \mathrm{~mm})$ dibandingkan dengan perlakuan dengan penambahan asam laktat $(\mathrm{d}=22,55 \pm 0,33 \mathrm{~mm})$, keduanya setelah pemanasan 30 menit dengan pola grafik relatif sama. Aktivitas anti E. coli untuk seluruh perlakuan tergolong dalam kategori aktivitas antibakteri tinggi karena memiliki nilai diameter zona hambat lebih dari $12 \mathrm{~mm}$. Bakteri E. coli merupakan bakteri Gram negatif (Buckle dkk., 1987) dengan pH optimum 7,0-7,5. Pada perlakuan dengan penambahan asam laktat dan asam suksinat maka kisaran $\mathrm{pH}$ produk emulsifier plus $\mathrm{PKO}$ relatif rendah, sehingga juga turut berkontribusi memperkuat daya antimikroba produk akhir.

\section{Aktivitas Anti Kultur Campuran Mikroba Alami}

Rata-rata nilai diameter zona hambat produk emulsifier plus PKO terhadap kultur campuran mikroba alami berkisar antara 3,79 $( \pm 0,07)$ sampai $6,46( \pm 0,24) \mathrm{mm}$. Hasil analisis ragam menunjukan bahwa jenis asam organik berbeda nyata terhadap aktivitas anti kultur campuran mikroba alami pada taraf nyata $5 \%$, sedangkan berdasarkan lama pemanasan dan interaksi antara jenis asam dengan lama pemanasan berbeda nyata terhadap aktivitas anti kultur campuran mikroba alami pada taraf nyata $1 \%$. Hasil uji lanjut polinomial ortogonal (Gambar 4) menunjukan bahwa hubungan antara jenis asam organik dan lama pemanasan terhadap aktivitas anti kultur campuran mikroba alami bersifat kuadratik.

Nilai diameter zona hambat tertinggi produk emulsifier plus PKO terdapat pada perlakuan penambahan asam

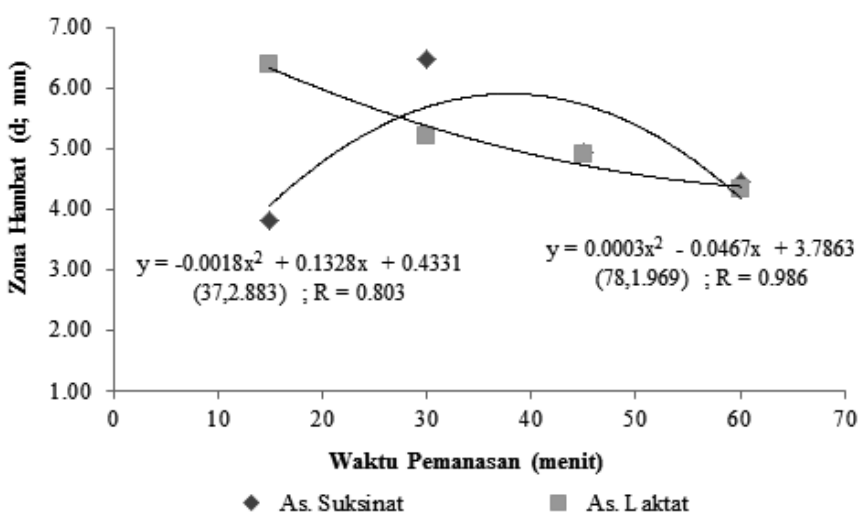

Gambar 4. Aktivitas anti kultur campuran mikroba alami produk emulsifier plus $\mathrm{PKO}$ pada lama pemanasan $\left(60^{\circ} \mathrm{C}\right)$ berbeda

suksinat setelah pemanasan 30 menit, yaitu sebesar $6,46( \pm$ $0,24) \mathrm{mm}$, sedangkan nilai tertinggi diameter zona hambat pada perlakuan penambahan asam laktat setelah pemanasan 15 menit, yaitu sebesar $6,37( \pm 0,17) \mathrm{mm}$, selanjutnya dengan pola terus menurun setelah pemanasan 30, 45 dan 60 menit. Nilai zona hambat produk terhadap kultur campuran mikroba alami lebih rendah dibandingkan terhadap E. coli dan $S$. aureus. Hal tersebut diduga dipengaruhi oleh banyaknya ragam mikroba pada kultur campuran mikroba alami yang diambil langsung dari saluran air buangan suatu rumah makan, sehingga ada jenis mikroba yang relatif tahan terhadap produk emulsifier plus PKO. Aktivitas anti kultur campuran mikroba alami dari produk emulsifier plus PKO tergolong ke dalam kategori aktivitas antibakteri kurang aktif (diameter 6-9 mm) (El-Masry dkk., 2000).

\section{Aktivitas Anti S. cerevisiae}

Secara umum produk emulsifier plus PKO memiliki senyawa anti $S$. cerevisiae dengan rentang nilai diameter zona hambat antara 5,59 $( \pm 0,24)$ sampai 8,84 $( \pm 0,08)$ $\mathrm{mm}$. Hasil analisis ragam menunjukan bahwa penambahan jenis asam organik, lama pemanasan dan interaksi antara jenis asam organik dengan lama pemanasan berbeda nyata terhadap aktivitas anti $S$. cerevisiae pada taraf nyata $1 \%$. Berdasarkan hasil uji lanjut polinomial orthogonal (Gambar 5), menunjukan bahwa hubungan antara jenis asam organik dan lama pemanasan terhadap aktivitas anti $S$. cerevisiae bersifat kuadratik.

Nilai tertinggi aktivitas anti $S$. cerevisiae produk emulsifier plus PKO terdapat pada perlakuan dengan penambahan asam suksinat setelah pemanasan 30 menit, yaitu sebesar $8,84 \mathrm{~mm}$, sedangkan nilai tertinggi pada penambahan asam laktat sebesar $7,46 \mathrm{~mm}$ juga setelah pemanasan 30 menit, keduanya dengan pola hampir sama dengan aktivitas anti E. coli. Produk emulsifier plus PKO ini tergolong dalam aktivitas anti khamir khususnya $S$. cerevisiae 


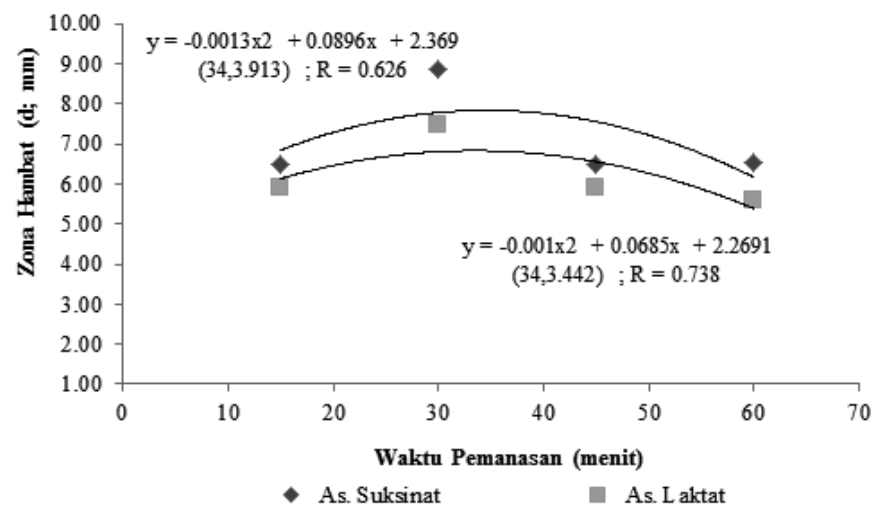

Gambar 5. Aktivitas anti S. cerevisiae produk emulsifier plus PKO pada lama pemanasan $\left(60^{\circ} \mathrm{C}\right)$ berbeda

yang kurang aktif (6-9 mm). Hasil penelitian Suharyono dkk. (2013), nilai diameter zona hambat produk etanolisis PKO dengan penambahan asam suksinat $40 \%$ dengan lama waktu pemanasan selama 15 menit pada suhu $60{ }^{\circ} \mathrm{C}$ terhadap $S$. cerevisiae, yaitu sebesar 4,74 $\mathrm{mm}$, termasuk golongan sangat lemah, karena kurang dari 6 mm (El-Masry dkk., 2000).

Saccharomyces cerevisiae termasuk ke dalam genus Saccharomyces yang merupakan mikroorganisme bersel satu tidak berklorofil, termasuk termasuk kelompok Eumycetes, tumbuh baik pada suhu $30{ }^{\circ} \mathrm{C}$ dan $\mathrm{pH} 4,8$ (Camacho-Ruiz dkk., 2003). Produk emulsifier plus PKO ini tergolong kurang aktif (diameter hambat 6-9 $\mathrm{mm}$ ) dalam menghambat $S$. cerevisiae. Kondisi ini terjadi karena S. cerevisiae memiliki beberapa kelebihan antara lain dalam proses fermentasi yaitu mikroorganisme ini cepat berkembang biak, tahan terhadap kadar alkohol yang tinggi, tahan terhadap suhu yang tinggi, mempunyai sifat stabil dan cepat mengadakan adaptasi (Anonim, 2016). Pelarut yang digunakan pada proses produksi produk emulsifier plus PKO yaitu etanol teknis sehingga besar kemungkinan $S$. cerevisiae masih dapat tumbuh dengan baik karena sifatnya yang tahan terhadap kadar alkohol tinggi (Anonim, 2016) meskipun produk tersebut mengandung asam.

\section{Daya Stabilitas Emulsi Produk Emulsifier Plus PKO}

Peningkatan daya stabilitas emulsi (\%) santan uji oleh produk emulsifier plus PKO yang dihasilkan pada penelitian ini, disajikan pada Gambar 6. Penambahan produk emulsifier plus PKO sebesar $5 \%$ (v/v) menyebabkan seluruh daya stabilitas emulsi memilki nilai positif yang berarti stabilitas emulsi mengalami peningkatan. Penambahan produk emulsifier plus PKO sebesar $5 \%$ (v/v) sudah cukup untuk meningkatkan stabilitas santan kelapa segar dibandingkan dengan kontrol.

Nilai rata-rata perubahan stabilitas emulsi berkisar antara $10,00( \pm 1,36)$ hingga $18,02( \pm 5,59) \%$ pada produk

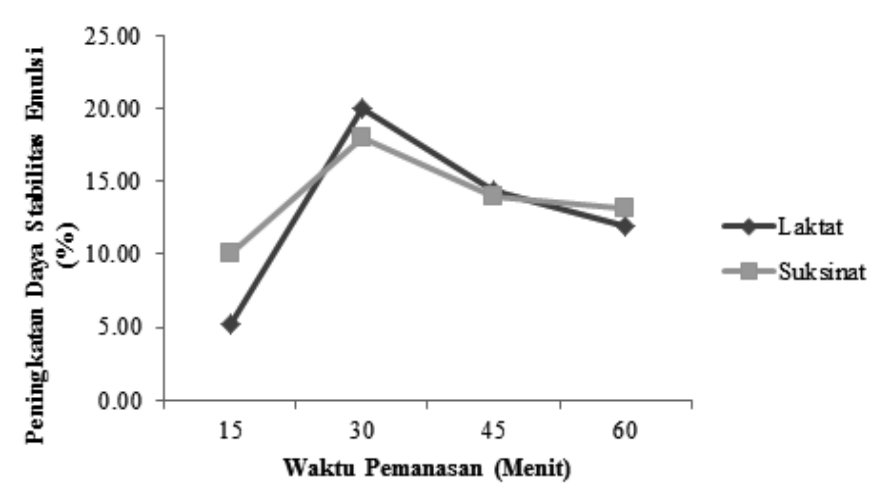

Gambar 6. Daya stabilitas emulsi produk emulsifier plus PKO pada lama pemanasan $\left(60^{\circ} \mathrm{C}\right)$ berbeda

emulsifier plus PKO dengan penambahan asam suksinat, sedangkan pada produk emulsifier plus PKO dengan penambahan asam laktat nilai rata-rata perubahan stabilitas emulsi berkisar antara 5,20 $( \pm 0,65)$ hingga 20,00 $( \pm 2,55)$ $\%$. Perubahan stabilitas emulsi terbaik dihasilkan oleh produk emulsifier plus $\mathrm{PKO}$ dengan penambahan asam laktat setelah pemanasan 30 menit, yaitu sebesar 20,00 $( \pm 2,55) \%$, sedangkan dengan penambahan asam suksinat juga setelah pemanasan 30 menit, yaitu sebesar 18,02 $( \pm 5,59) \%$.

\section{KESIMPULAN}

Jenis asam organik, lama pemanasan serta interaksi antara jenis asam organik dan lama pemanasan berpengaruh nyata terhadap derajat keasaman $(\mathrm{pH})$, aktivitas antimikroba (anti S. aureus, anti E. coli, anti kultur campuran mikroba alami, dan anti S. cereviciae) serta daya stabilitas emulsi santan segar. Kondisi optimum produksi produk emulsifier plus PKO yaitu dengan penambahan asam suksinat $40 \%$ (b/b) dengan lama pemanasan $\left(60^{\circ} \mathrm{C}\right) 30$ menit yang menghasilkan daya antimikroba rata-rata dengan diameter zona hambat sebesar $13,04( \pm 0,27) \mathrm{mm}$ (tergolong aktivitas antimikroba tinggi, $\mathrm{d}$ $>12 \mathrm{~mm}$ ) dan mampu meningkatkan stabilitas emulsi santan kelapa segar sebesar 18,02 $( \pm 5,59) \%$.

\section{UCAPAN TERIMA KASIH}

Peneliti mengucapkan terima kasih kepada Direktorat Penelitian dan Pengabdian kepada Masyarakat (DP2M), Direktorat Jenderal Pendidikan Tinggi - Kemendikbud RI, Jakarta dan Lembaga Penelitian dan Pengabdian kepada Masyarakat (LPPM) Universitas Lampung, Bandar Lampung, yang telah membantu pembiayaan penelitian ini yaitu dari Program Penelitian Hibah Strategis Nasional (Stranas) Tahun Anggaran 2013. 


\section{DAFTARA PUSTAKA}

Affandi, R.A. (2007). Sintesis Mono dan Diasilgliserol dari Minyak Inti Sawit dengan Metode Gliserolisis. Skripsi. Fakultas Teknologi Pertanian IPB, Bogor.

Anonim. (2016). Saccharomyces. https://id.wikipedia.org/ wiki/Saccharomyces. [24 Februari 2016].

Bautista, D.A., Hill, A.R., dan Griffiths, M.W. (1993). An all natural approach to preserve cottage cheese. Modern Dairy 72(1):12-13.

Buckle, K.A., Edwards, R.A., Fleet, G.H., dan Wootton, M. (1987). Ilmu Pangan: diterjemahkan oleh Purnomo dan Aldino. UI-Press. Jakarta. $365 \mathrm{hlm}$.

Camacho-Ruiz, L., Pérez-Guerra, N., dan Roses, R.P. (2003). Factors affecting the growth of Saccharomyces cerevisiae in batch culture and in solid state fermentation. Electronic Journal of Environmental, Agricultural and Food Chemistry 2(5): 531-542.

Cotton, L.N. dan Marshall, D.L. (1997). Monolaurin preparation methods effects activity against vegetative cell of Bacillus cereus. Journal of Food Science \& Technology 30(8): 830-832.

El-Masry, A.H., Fahmy, H.A., dan Abdelwahed, S.H.A. (2000). Synthesis and antimicrobial activity of some new benzimidazole derivatives. Journal of Molecules 5: $1429-1438$

Fennema, O.R. (1985). Food Chemistry, Second Edition, Revised and Expanded. Maecel Dekker, Inc. New York.

Gariga, M., Hugas, M., Aymerich, T., dan Monfort, J.M. (1983). Bacteriogenic activity of Lactobacilli from fermented sausage. Appiled Bacteriology 75: 142-148.

Kovacs, A., Schluchter, M., dan Easley, K. (1999). Cytomegalovirus infection and HIV-1 disease progressionin infant born to HIV-1-infected women. New England Journal of Medicine 341: 77-84.

Kurniawan, R., Murhadi, Hidayati, S. (2014). Pengaruh jenis asam dan suhu reaksi pemanasan pada produk etanolisis PKO (Palm Kernel Oil) terhadap aktivitas antimikroba dan daya stabilitas emulsi. Majalah TEGI 6(1): 21-33.

Lestari, M. dan Murhadi. (2008). Pengaruh nisbah etanolPKO dan waktu reaksi terhadap rendemen dan aktivitas antibakteri produk etanolisis minyak inti sawit (PKO). Jurnal Teknologi \& Industri Hasil Pertanian 13(2):95107.

Malik, D., Fardiaz, D., dan Jenie, B.S.L. (1987). Pengaruh karboksimetil selulosa terhadap kestabilan emulsi dan mutu krim kelapa. Media Teknologi Pangan 3(1-2): 62.
Mappiratu. (1999). Penggunaan Katalis Dedak Padi dalam Biosintesis Anti-Mikroba Monoasilgliserol dari Minyak Kelapa. Disertasi. Institut Pertanian Bogor, Bogor.

Mappiratu, Fardiaz, D., dan Hasanuddin, A. (2003). Produksi dan aplikasi produk monoasilgliserol dari minyak kelapa dalam pengolahan santan awet. Jurnal Teknologi dan Industri Pangan 14(3): 233-240.

Murhadi, Suharyono, A.S., dan Susilawati. (2007). Aktivitas antibakteri ekstrak daun salam dan daun pandan. Jurnal Teknologi dan Industri Pangan 18(1): 17-24.

Murhadi dan Suharyono, A.S. (2008). Kajian aktivitas antibakteri produk etanolisis dari campuran minyak inti sawit (Elaeis quineensis Jacq) dan minyak biji mengkudu (Morinda citrifolia L.). Jurnal Teknologi dan Industri Hasil Pertananian 14(2): 47-58.

Murhadi. (2009). Daya pengemulsi produk etanolisis dari campuran minyak inti sawit (Elaeis quineensis Jacq) dan minyak biji mengkudu (Morinda citrifolia L.) pada santan kelapa segar. Prosiding Seminar Sehari: Hasilhasil Penelitian dan Pengabdian Kepada Masyarakat. 5 Oktober 2009. Bandar Lampung. Hal. B-66 - B-71.

Murhadi dan Zuidar, A.S. (2009). Penganekaragaman Bahan Tambahan Pangan (BTP) Berbasis Minyak Inti Sawit. Laporan Akhir Hibah Bersaing, Tahun Pertama. Lembaga Penelitian Unila, Bandar Lampung.

Murhadi. (2010a). Antimikroba dari Tanaman: Golongan Senyawa, Sumber, dan Aktivitasnya, Cetakan Pertama. Lembaga Penelitian Universitas Lampung, Bandar Lampung.

Murhadi. (2010b). The emultion stability of coconut (Cocos nucifera L.) milk added with ethanolysis product from palm kernel oil (Elaeis queneensis Jack). Proceeding International Seminar on Horticulture to Support Food Security, 22-23 Juni 2010. Bandar Lampung. Hal. B-223-B-229.

Murhadi, Zuidar, A.S., dan Rahman, A. (2010). Yield and antibacterial activities of crude ethanolysis products of PKO produced on different temperatures reaction. Oral Presentation on International Seminar: Emerging Issues and Technology Developments in Food and Ingredients. 29-30 September 2010. Jakarta.

Murhadi dan Suharyono, A.S. (2012). Optimalisasi Produksi Produk Etanolisis Kasar dari Campuran CPO dan PKO dengan Reaksi Etanolisis Bertahap. Laporan Akhir Penelitian Unggulan Perguruan Tinggi. Universitas Lampung, Bandar Lampung. 
Oh, D.H. dan Marshall, D.L. (1994). Enhanced inhibition of Listeria monocytogenes by glycerol monolaurat with organic acids. Journal of Food Science 59(6): 12581261.

Rangga, A., Murhadi, Nuraeni, F., dan Pitutur. (2005). Produksi dan kajian aktivitas antibakteri produk gliserolisis dari minyak inti sawit (PKO). Bahan Seminar Nasional Research and Studies TPSDP Dikti Depdiknas. Mei 2005. Yogyakarta.

Suharyono, A.S., Murhadi dan Hidayati, S. (2013). Aktivitas Antibakteri dan Daya Stabilitas Emulsi Produk Emulsifier Plus dari Minyak Inti Sawit. Laporan Penelitian Hibah Strategis Nasional T.A. 2013. DP2M Dikti-Lembaga Penelitian Unila, Kemendikbud RI. Jakarta.
Triana, R.N., Andarwulan, N., Affandi, A.R., Wincy, dan Kemenady, E. (2014). Aplikasi mono-diasilgliserol dari Fully Hydrogenated Palm Kernel Oil sebagai emulsifier untuk margarin. Jurnal Mutu Pangan 1(2): 137-144.

Wang, L.L., Yang, B.K., Parkin, K.L., dan Johnson, E.A. (1993). Inhibition of Listeria monocytogenes by monoacylglyceros synthesized from coconut oil and milk fat by lipase-catalyzed glycerolysis. Journal of Agriculture Food Chemistry 41: 1000-1005. 